\title{
Tolerancija - od podnošenja do krjeposti
}

\author{
JERKo VALKOVIĆ* \\ UDK: $172.3^{*} 2-42$ • Pregledni članak \\ Primljeno: 22. listopada 2017. • Prihvaćeno: 18. lipnja 2018.
}

Sažetak: Prisutnost različitih svjetonazora, vrijednosnih sustava, kultura i religija koje obilježava današnje pluralno društvo aktualizira govor o toleranciji. U ovom radu autor ne govori o toleranciji kao »nužnom načelu《 suživota unutar jednoga društva. Isto tako ne promatra toleranciju samo kao »podnošenje $\ll$ različitih stavova ili mišljenja. Autor promišlja o utemeljenju tolerancije polazeći od same osobe. Toleranciju promatra kao moralni stav osobe koja poštuje slobodu drugoga i njegov put u traženju istine. Prihvaćanje drugoga kao osobe temelj je autentične tolerancije. Krjepost tolerancije nije samo jedno od >obilježja osobnosti, već je ona habitus, prožima čovjekovu

${ }^{*}$ Izv. prof. dr. sc. Jerko Valković, Hrvatsko katoličko sveučilište u Zagrebu, Ilica 242, 10000 Zagreb, Hrvatska, jerko.valkovic@unicath. hr; Teologija u Rijeci, Područni studij KBF-a Sveučilišta u Zagrebu, 51000 Rijeka, Hrvatska. nutrinu, a prepoznaje se i u djelovanju na raznim područjima čovjekova života. Krjepost tolerancije pretpostavlja stalni rast $i$ sazrijevanje, a vjernik, promatrajući Božju ljubav, u vjeri nalazi nadahnuće za tolerantno djelovanje.

Ključne riječi: tolerancija, krjepost tolerancije, osoba, podnošenje, istina, dijalog.

\section{Uvod}

Danas nije potrebno isticati aktualnost govora o toleranciji ako imamo u vidu činjenicu da u pluralnom društvu sužive različiti svjetonazori, vrijednosni sustavi, kulture i različite religije te da svjedočimo brojnim sukobima na socijalnoj, političkoj, kulturnoj ili svjetonazorskoj sceni. Koliko god izgledalo neobično, ali upravo u sredinama obilježenim različitim (i nerijetko suprotstavljenim) shvaćanjima, sve se više osjeća potreba za tolerancijom. Različita su područja, odnosno razine, na kojima se vidi njezina aktualnost: bilo da je riječ o međuljudskim odnosima, o grupama ili od- 
nosima na globalnim razinama. Već prije više desetljeća moralni teolog Bernhard Häring rekao je da možda nikad kao danas ljudski rod, upravo zato da bi mogao preživjeti, nije imao veću potrebu za tolerancijom. ${ }^{1} \mathrm{U}$ toleranciji on vidi jedno od najvažnijih načela društvenoga života, te je stavlja uz bok solidarnosti i bratstvu. Iako govor o toleranciji podrazumijeva različitost, želimo odmah na počeku spomenuti da se razlike (pa u određenoj mjeri i sukobi) ne moraju nužno promatrati samo u negativnom kontekstu. Naime različita mišljenja, stavovi i napetosti sastavni su dio života svakoga društva. Društveni život nije nešto statično što bi bilo jednom zauvijek definirano, već svako društvo prolazi kroz procese koji uključuju i susrete i sučeljavanje s onima koji misle i djeluju drukčije.

\section{Razvojni put pojma tolerancije}

Riječ tolerancija dolazi od latinske riječi tolerantia (od glagola tolerare), a ona se najčešće prevodi sljedećim pojmovima: podnošenje, snošljivost, trpeljivost, uvažavanje, obzirnost, dopušteno odstupanje od uobičajenih pravila. ${ }^{2}$ Spomenuti pojmovi toleranciju prikazuju kao stanje ili sposobnost podnošenja nečega što bi moglo biti ili jest neugodno, štetno ili nepodnošljivo. Ipak, uz spomenuta čini se da je potrebno ukazati i na neka druga obilježja kako bi potpunije razumjeli značenje tolerancije.

Njemački filozof Forst kaže da u govoru o toleranciji posebnu pozornost treba obratiti na kontekst u kojem se o njoj govori. Pritom ističe važnost odnosa koji se uspostavlja između osobe koja tolerira i osobe koju se tolerira. Takav odnos treba promatrati ne samo kada je riječ o odnosima između pojedinaca već također i unutar društva, kao i šire globalne zajednice. Upravo je ta odrednica, prema njegovu mišljenju, osobito važna. ${ }^{3}$ Osim toga Forst kaže da bi onomu tko je tolerantan trebali biti jasni razlozi zbog kojih je spreman tolerirati drugoga ili, u suprotnom, zbog kojih ne želi biti tolerantan. Isto tako potrebno je odrediti granice tolerancije odnosno netolerancije jer je područje tolerancije ograničeno, te se neograničena (bezuvjetna) tolerancija ne može prihvatiti. ${ }^{4} \mathrm{Uz}$ to Forst kaže da se tolerancija uvijek temelji na slobodnoj odluci, a to znači da se nikoga ne može prisiliti da bude tolerantan ako to on ne želi. Drugim riječima, tolerancija je plod slobodne odluke pojedinca.

${ }^{1}$ Usp. B. HÄRING, V. SALVOLDI, Tolerance: Towards an Ethic of Solidarity and Peace, New York, 1995., X.

${ }^{2}$ Usp. B. KLAIĆ, Tolerancija, u: Rječnik stranih riječi, Zagreb, 2007., 1357.

${ }^{3}$ Usp. R. FORST, Toleranz im Konflikt. Geschichte, Gehalt und Gegenwart eines umstrittenen Begriffs, Frankfurt am Main, 2014., 31.

${ }^{4}$ Isto, 38. 
Polazeći od spomenutih karakteristika, vidljivo je da se tolerancija ne može odrediti samo negativno-pasivnim vidom ( $\mathrm{t}$. samo kao podnošenje). Treba svakako spomenuti da i UNESCO-ova definicija tolerancije iz 1995. godine sasvim jasno ističe njezin aktivni vid: »Tolerancija nije koncesija, dobrodušnost ili popustljivost. Tolerancija je, iznad svega aktivan stav potaknut priznanjem univerzalnih ljudskih prava i fundamentalne slobode drugih. $\ll^{5}$

Budući da nije namjera ovoga teksta na detaljan način prikazati razvitak tolerancije kroz povijest, istaknut ćemo samo neke značajnije naglaske. Mnogo prije negoli je $\mathrm{u}$ 16. st. pojam tolerancija ušao u europsku kulturu (tada se pod tim pojmom podrazumijevalo dopuštenje vezano uz vjersku slobodu podložnika koji nisu pripadali vjeri kralja, kneza ili državnoj religiji), u mnogim starim kulturama prepoznavala se njezina važnost za život društva. ${ }^{6}$ Naime već je prisutnost različitih religija pobuđivala pitanje o onima koji se razlikuju u vjerovanju (npr. heretici ili nevjernici). Mirko Jozić kaže da se u starom vijeku o toleranciji govori i taj se pojam pokušava razumjeti analizirajući pojam stranac. ${ }^{7}$ Naime stranac označava onoga tko je drukčiji. Prema njemu (strancu) mogu se zauzimati različiti stavovi. Dok s jedne strane stranac može biti ugroza (jer ugrožava homogenost zajednice), s druge strane prema njemu se može očitovati gostoljubivost i povjerenje.

Samu riječ tolerancija prvi put spominje rimski filozof Ciceron 46. godine prije Krista u djelu Paradoxa stoicorum. ${ }^{8}$ Ciceron taj pojam upotrebljava kada govori o podnošenju sudbine i prezira. $U$ tom tekstu on na toleranciju gleda kao na krjepost, a središnji je naglasak na samom stavu osobe koja tolerira. Naime tolerancija predstavlja sposobnost podnošenja koja se temelji na jakosti osobe. Ta jakost nije nešto čime je osoba sama po sebi obdarena, već se ona razvija radom na samome sebi. Cilj je usavršavanje, odnosno osposobljavanje osobe kako bi mogla vladati sama sobom.

${ }^{5}$ Declaration of Principles on Tolerance, (16. 11. 1995.) article 1.2., u: http://portal.unesco.org/en/

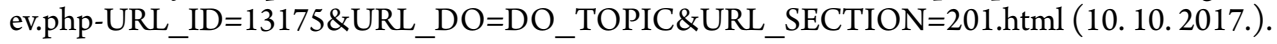

${ }^{6}$ Upućujemo na neke tekstove koji govore o toleranciji u starim društvima: P. GARNSEY, Religious Toleration in Classical Antiquity, u: W. J. SHEILS (ur.), Persecution and Toleration, Oxford, 1984., 1-28.; J. ASSMAN, Praktiken des Überssetzens und Konzepte von Toleranz im Alten Orient und in der hellenistische-römischen Antike, u: A. WIERLACHER (ur.), Kulturthema Toleranz, München, 1996., 283.-306.

${ }^{7}$ Usp. M. JOZIĆ, Tolerancija - povijest jedne ideje, u: Bosna Franciscana 38(1995.), 10-21., ovdje 11-12.

${ }^{8}$ CICERO, Paradoxa Stoicorum, u: De oratore, IV, Cambridge, 1948., 278., citirano prema R. FORST, Toleranz im Konflikt, 54. 
Kod crkvenih otaca prvih stoljeća nailazimo na slično razumijevanje tolerancije. Ističe se sposobnost podnošenja drugoga te nelagodnih ili teških situacija. ${ }^{9}$ Teolog Tenšek donosi neka polazišta, odnosno načela na temelju kojih su kršćanski pisci prvih stoljeća prihvaćali i opravdavali toleranciju: naravno pravo zahtijeva da se svaka osoba klanja komu hoće; dragovoljnost, odnosno spontanost, spada u bit religije (božanstvu nisu drage žrtve koje se silom prikazuju); sila je najgori instrument propagande i očit znak sloma jedne religije; religija se ne brani ubijajući, nego umirući po Kristovu primjeru. ${ }^{10}$

Značajne promjene u shvaćanju tolerancije dogodit će se kada rimski car Galerije Ediktom o toleranciji 311. godine okonča progone kršćana u Carstvu, a kršćanstvo pravno izjednači s drugim religijama. ${ }^{11}$ Ubrzo nakon toga Milanskim ediktom 313. godine kršćanstvo dobiva status priznate religije, a 380. godine postaje državnom religijom. U takvom novom društvenom kontekstu aktualizira se pitanje o toleranciji: Treba li poganima, hereticima i Židovima omogućiti onu istu toleranciju koju su za sebe zahtijevali kršćani u vrijeme prognanstva?

Posebnu pozornost toj temi posvetio je sv. Augustin. On smatra da toleranciju treba promatrati kao stav koji uključuje odnos prema sebi, prema Bogu i prema drugima. ${ }^{12}$ Više je razloga zbog kojih bi se tolerancija trebala prihvaćati. Najprije, tolerancija znači podnošenje grješnosti ljudske naravi. Ona je isto tako potrebna zbog čovjekove nemogućnosti ostvarenja sreće na zemlji i na koncu ona je potvrda nade u milosrdnoga Boga. Tolerancija je utemeljena na ljubavi koja se nadahnjuje na Božjoj ljubavi prema čovjeku. Augustin se poziva na prispodobu o kukolju i žitu (Mt 13, 24-43). Bog je predvidio da u Crkvi skupa s dobrima budu i zli prema kojima treba biti tolerantan. Naime sam Bog pokazuje se tolerantnim prema grješniku jer dopušta da kukolj raste zajedno s pšenicom. Zato kaže da će potreba za tolerancijom na ovom svijetu uvijek postojati jer je zlo stalno prisutno i neizbježno. ${ }^{13}$ Štoviše, Augustin ne samo da prihvaća toleranciju već i smatra da je kušnja tolerancije

\footnotetext{
${ }^{9}$ Tertulijan, govoreći o podnošenju progona kojima su kršćani bili izloženi u prvim stoljećima, govori o krjeposti tolerancije (virtus tolerantiae). TERTULILLIAN, De fuga in persecutione, u: Corpus hispanorum seu nova patrum colletivo, series latina, II, Turnhout, 1956., 2, 7, citirano prema R. FORST, Toleranz im Konflikt, 55-56.

${ }^{10}$ Usp. T. Z. TENŠEK, Religijski pojam tolerancije u patrističko doba, u: Društvena istraživanja 5 (1996.), 389-398., ovdje 391.

${ }^{11}$ Usp. K. BAUS, Von der Urgemeinde zur frühchristlichen Großkirche, u: H. JEDIN, Handbuch der Kirchengeschichte, I, Freiburg - Basel - Wien, 1962., 441-449.

${ }^{12}$ Usp. A. AUGUSTIN, O državi Božjoj. De civitate Dei, III, Zagreb, 1996., 14., 19.

${ }^{13}$ Kod Augustina tolerancija je kršćanska dužnost $\mathrm{i} \gg$ zakon ljubavi« koji spašava jedinstvo Crkve kako ističe Mužić tumačeći njegovu misao. Usp. J. MUŽIĆ, Tolerancija zlih kod Augustina prema prispodobi o žitu i kukolju, u: Služba Božja 52(2012.)3, 404-436., ovdje 408.
} 
za vjernika put jačanja u vjeri: »Naime, svi neprijatelji Crkve, kojom god zabludom zaslijepljeni ili zloćom, izopačeni, steknu li ovlast da naude tjelesno, vježbaju njezinu strpljivost, ako joj se opiru tek zlim mnijenjem, vježbaju njezinu mudrost; što više, kako bi se čak i neprijatelji ljubili, takvi vježbaju i njezinu dobrohotnost ili dobrotvornost: bilo da se s njima postupa uz uvjerljiv nauk bilo u strogoj stezi. « ${ }^{14}$

Drugi razlog zbog kojeg Augustin prihvaća toleranciju jest očuvanje jedinstva. Komentirajući slučaj raskola biskupa Cecilijana za kojeg su držali da je izdajnički djelovao za vrijeme progona, Augustin kaže da mu nije dokazana krivica i da je proglašen nevinim. Ali kad bi i bio kriv » bilo bi razboritije i strpljivije svjesno tolerirati jednog grešnika, negoli se odvojiti bezbožnim raskolom od tolikih nevinih koji nisu znali ništa $\ll .{ }^{15}$ Sljedeći argument koji Augustin spominje u korist tolerancije, a na njega će se kasnije mnogi referirati, potreba je priznavanja slobode izbora, odnosno neprisiljavanje na vjerovanje (to govori imajući u vidu odnos prema nevjernicima). Poznate su njegove riječi: Credere non potest homo nisi volens - čovjek ne može vjerovati osim ako to hoće. ${ }^{16}$

U kasnijim je stoljećima Crkva imala poteškoća s prihvaćanjem tolerancije. Kako ističe crkveni povjesničar Grbešić, u pojedinim razdobljima ona se čak doživljavala kao grijeh: ${ }^{17}$

- protiv istine jer se smatralo se da se toleriranjem krivovjerja istinu i zabludu stavlja na istu razinu (što se nije moglo prihvatiti)

- protiv ljubavi jer bi se toleriranjem dopustilo krivovjercu da ostane u svojoj zabludi te bi mu se na taj način otvarao put vječne propasti; zato bi tolerancija $u$ tim slučajevima bila neprihvatljiva

- protiv jedinstva domovine jer toleriranje religioznoga pluralizma može biti opasnost za državno jedinstvo. ${ }^{18}$ Prvo ostvarenje osnovnoga načela tolerancije kao

${ }^{14}$ A. AUGUSTIN, O državi Božjoj. De civitate Dei, II, Zagreb, 1995., 18., 51.

${ }^{15}$ ISTI, Contra Cresconium grammaticum Donatistam, IV, 56., 67., u: https://www.augustinus.it/latino/contro_cresconio/index $2 . h t m(11.10 .2017$.

${ }^{16}$ Usp. isto, II, 35. Augustin kasnije mijenja stav prema toleranciji. Dopušta upotrebu sile kada je riječ o obraćenju (to se odnosilo samo na raskolnike, a ne na inovjerce ili pogane). Augustin kaže: Compelle intrare. - Prisili ih neka uđu. Takav Augustinov stav treba promatrati u svjetlu parabole o

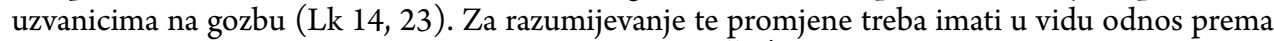
donatistima i ondašnjim državnim vlastima. Usp. J. MUŽIĆ, Tolerancija zlih kod Augustina prema prispodobi o žitu i kukolju, 427-430.

${ }^{17}$ Usp. G. GRBEŠIĆ, Poimanje i primjena tolerancije u progonjenoj, slobodnoj Konstantinovoj i državnoj Crkvi, u: Bogoslovska smotra 83(2013.)2, 287-308., ovdje 289.

${ }^{18}$ Kršćanska država nastojala je u jedinstvu religije kao nosivoga stupa identiteta. Važnost toga načela bila je osobito aktualna kada se zbog reformacije i vjerskih ratova nalomilo jedinstvo kršćanske 
državne maksime dogodilo se Ediktom iz Nantesa (1598.) kralja Henrika IV. Međutim stvarno stanje bilo je dosta drukčije jer su »religiozna stajališta i stajališta vlasti još uvijek bila previše međusobno isprepletena da bi se to osnovno načelo moglo trajno probiti ${ }_{.}{ }^{19}$

Velike promjene u shvaćanju tolerancije dogodit će se u vrijeme prosvjetiteljstva. Jedno od važnih obilježja toga vremena jest da u središte dolazi osoba te sve više jača svijest o ljudskim pravima koje (država) treba jamčiti bez obzira na osobni svjetonazor. Tolerancija više ne će ovisiti o blagonaklonosti, odnosno dobroj volji vladara. Treba spomenuti da u jačanju svijesti o toleranciji kao i slobodi religije, odnosno slobodi savjesti, nije glavni promotor bilo kršćanstvo, već prosvjetiteljstvo. ${ }^{20}$ Štoviše, Crkva je na te promjene, odnosno novu duhovnu klimu, gledala sa zadrškom ili otvorenim protivljenjem. ${ }^{21}$

Iako je presudan trenutak u shvaćanju tolerancije unutar Crkve bio Drugi vatikanski sabor, već od pape Leona XIII. nalazimo navještaj temeljnih ideja s obzirom na poštivanje slobode savjesti, odnosno dostojanstva ljudske osobe. ${ }^{22}$ Spomenuta prava bit će istaknuta u koncilskoj deklaraciji Dignitatis humanae, a polazište je za takav stav priznavanje dostojanstva osobe: »Dostojanstvo ljudske osobe u ovo naše doba iz dana u dan sve više prodire u svijest ljudi; isto tako raste broj onih koji zahtijevaju da ljudi u djelovanju imaju i služe se svojom vlastitom odlukom i odgovornom slobodom te da ne budu pokretani prisilom, nego vođeni sviješću dužnosti. Oni

vjere. Zato su jedinstvo religije i države protestantski, kao i katolički, knezovi doživljavali veoma potrebnim. Nakon mira u Augsburgu (1555.) prihvaća se da se države dijele na konfesionalnoj osnovi (u svakoj državi samo je jedna religija dopuštena). Koncem 16 st. nastaje poznata uzrečica: cuius regio, illius religio. (Usp. isto, 289.)

${ }^{19}$ F.-X. KAUFMANN, Kako da preživi kršćanstvo?, Zagreb, 2003., 50.

${ }^{20}$ Usp. S. KUŠAR, Utjelovljenje Sina Božjega - promocija tolerancije?, u: Vjesnik Đakovačke i Srijemske biskupije 15(1995.), 577-581., ovdje 579.

${ }^{21}$ U kontekstu novovjekovnoga shvaćanja slobode drukčija su polazišta i za shvaćanje tolerancije. Ona se sve više počinje razumjeti kao jedan oblik prava. Drukčija mišljenja treba prihvatiti prema načelu reciprociteta. Tako se tolerancija u liberalnoj perspektivi sve više povezuje s pojmom pravednosti i slobode.

${ }^{22}$ Sredinom prošloga stoljeća Pio XII. govori o odnosu vjerske slobode, tolerancije i općega dobra. Upućuje na »političku, civilnu i socijalnu toleranciju prema sljedbenicima drugih konfesija «. PIO XII., Allocuzione al tribunale della S. Rota, 6. listopada 1946., u: ASS 38(1946.), 393. Ali on pravo na slobodu afirmira samo za »istinsku vjeru «. »Ono što nije u skladu s istinom i moralnom normom, objektivno nema nikakvog prava ni postojati, niti se treba propagirati, niti djelovati.« PIO XII., Ci riesce, 6. prosinca 1953., u: ASS 35(1953.), 797. Radi ostvarenja općega dobra i društvenoga mira moguće je da vlasti toleriraju pogrješke kako bi se izbjegla veća zla. Tolerancija se shvaća kao jedan oblik manjega zla. Usp. A. COZZI, La libertà religiosa tra tolleranza e intolleranza. Uno sguardo alla Chiesa Cattolica, u: Lessico di Etica pubblica 2(2011.), 36-46., ovdje 39. 
isto tako zahtijevaju da se javnoj vlasti postave pravne granice kako se ne bi previše sužavala časna slobode i osobe i zajednica. Taj se zahtjev za slobodom u ljudskom društvu najviše odnosi na dobra ljudskoga duha, u prvom redu na ona koja se tiču slobodnoga prakticiranja religije u društvenoj zajednici. ${ }^{23}$

Ako je do tada polazište bilo pravo objavljene istine, Koncil u središte stavlja osobu kojoj Objava progovara. Uz središnje mjesto osobe ističe se njezina (moralna) obveza traženja istine. Iako koncilski tekstovi ne spominju izričito riječ tolerancija, ona se usko povezuje s pravom svake osobe da traži istinu. Koncilski tekst pravo osobe na traženje istine usko povezuje s pitanjem slobode jer osobe ne mogu tražiti istinu ako »ne uživaju psihološku slobodu i, istodobno, izuzeće od izvanjskoga pritiska $\ll^{24}$. Kada je riječ o vjerskoj slobodi, Deklaracija donosi važno načelo: $\gg$ Pravo na slobodu vjerovanja nije, dakle, utemeljeno na subjektivnom raspoloženju osobe, nego na samoj njezinoj naravi. Zato pravo na tu nepovredivost ostaje i u onih koji ne udovoljavaju obvezi traganja za istinom i prianjanja uz nju; služenje tim pravom ne može se sprječavati dokle god se poštuje pravedan javni poredak. $\ll^{25}$ Pravo na vjersku slobodu, kako je u Deklaraciji istaknuto, postoji neovisno o tome je li riječ o ispravnoj vjeri ili nije. To pravo utemeljeno je na ontološkom dostojanstvu ljudske osobe, a ne na (nepostojećoj) jednakosti između religija.

Drugi vatikanski sabor tom Deklaracijom označava veliku promjenu mentaliteta, odnosno načina gledanja na slobodu savjesti, slobodu vjeroispovijesti i prava osobe na traženje istine. Na značajne promjene upozorava kardinal Lehmann kada kaže da u tom dokumentu prvi put crkveno učiteljstvo na tako jasan način preuzima bitne elemente slobode mišljenja i jasno razlikuje pravni poredak i moralne obveze. ${ }^{26}$ Koncilsko isticanje središnjega mjesta osobe izazov je za teologiju da mnogo veću pozornost posveti proučavanju osobe i njezine naravi. Pritom se ne bi smjelo ispustiti iz vida dvije bitne karakteristike osobe: sloboda i usmjerenost prema istini. U kontekstu govora o toleranciji poštivati slobodu drugoga znači s poštovanjem prihvaćati njegove stavove i njegov način razmišljanja (riječ je o prihvaćanju, a ne o bezuvjetnom usvajanju!). Prihvaćanjem slobode na neki način potvrđuje se dvostruko pravo osobe: pravo na vlastito uvjerenje (bez obzira na to je li ono u skla-

${ }^{23}$ DRUGI VATIKANSKI KONCIL, Deklaracija o vjerskoj slobodi $\gg$ Dignitatis humanae $\ll(=D H)$, u: ISTI, Dokumenti, Zagreb, ${ }^{7} 2008$. (= Dokumenti), br. 1 .

${ }^{24}$ Isto, br. 2.

${ }^{25}$ Isto.

${ }^{26}$ Usp. K. LEHMANN, Toleranz und Religionsfreiheit. Geschichte und Gegenwart in Europa, Freiburg Basel - Wien, 2015., 53. Važnost toga dokumenta ističe i Kasper koji u njemu prepoznaje temeljni kamen za novo polazište i izgradnju odnosa $\mathrm{u} \gg$ dugoj i veoma često konfliktnoj povijesti odnosa Katoličke crkve i modernoga shvaćanja slobode «. W. KASPER, Teologia e Chiesa, II, Brescia, 2001., 225-226. 
du s objektivnom istinom) te pravo na život po tom istom uvjerenju. Naučavanje Koncila o slobodi osobe, slobodi savjesti, traženja istine, bit će sastavnim dijelom Učiteljstva od Koncila do naših dana.

\section{Tolerancija kao krjepost}

U moralnom, odnosno vjerskom kontekstu krjepost označava dobro koje krjeposna osoba čini, ali isto tako sve osobine kojima je takva osoba obdarena i koje ju osposobljavaju da čini dobro. ${ }^{27} \mathrm{Nije}$ dakle riječ samo o dobru kao takvom već i o usmjerenosti osobe da čini dobro. Teolog Häring kaže da čovjeka čini krjeposnim to što je zahvaćen dobrom u svim svojim dimenzijama. ${ }^{28}$ To isto naglašava i grčki filozof Aristotel kada kaže da krjepost prožima sve čovjekove sposobnosti i sve njegove dimenzije: voljnu, afektivnu i kognitivnu. ${ }^{29}$ Zato govoriti o krjeposti ne znači usredotočiti se samo na neki konkretni čin, već krjepost treba gledati kao držanje ili stav. Ona je habitus. ${ }^{30}$ Ona se ne može tumačiti samo kao raspoloženje osobe jer su krjeposti postojane, a raspoloženja su podložna lakoj i brzoj promjeni. Isto tako ona nije samo prirodna sposobnost osobe jer krepost nije prirođena, već se stječe vježbanjem. Ona se ne izjednačava s čuvstvima jer čuvstva nisu predmet izbora, ali krjeposti jesu. Ono što je posebno važno istaknuti jest da je krjepost rezultat osobnoga odabira. Iako će neki gledati na krjepost samo kao unutarnju sposobnost osobe, sposobnosti ili moći krjeposnoga čovjeka odražavaju se u cjelokupnom čovjekovu djelovanju. Moralni teolog Häring kaže: »krepost je postojanost i lakoća u vršenju dobra što izvire iz najintimnije dobrote kreposnog čovjeka. ${ }^{31}$ Krjeposno djelovanje oplemenjuje čovjekove (nutarnje) sposobnosti, ali obogaćuje i njegovo djelovanje, odnosno cjelokupni društveni život. ${ }^{32}$ Zato Aristotel kaže da bi bez krjeposti i krjeposnih građana život u zajednici bio nemoguć jer ne bi bilo moguće ostvariti dobro zajednice, a da se ne govori o krjeposnim pojedincima. ${ }^{33}$

${ }^{27}$ Usp. D. MONGILLO, Virtù, u: F. COMPAGNONI, G. PIANA, S. PRIVITERA (ur.), Nuovo dizionario di teologia morale, Milano, 1990., 1450-1474., ovdje 1450.

${ }^{28}$ Usp. B. HÄRING, Kristov zakon. Opća kršćanska moralna teologija, I, Zagreb, 1973., 468.

${ }^{29}$ Usp. ARISTOTEL, Nikomahova Etika, II, Zagreb, 1988., 1105b 25-30.

${ }^{30} \mathrm{O}$ osnovnim karakteristikama krjeposti te posebno o krjeposti tolerancije vidi tekst: S. RADIĆ, Toleranz als Triebkraft von Demokratie und Menschenrechten: Eine Darstellung der Toleranz als Tugend. Zu anthropologischen Grundlagen der Toleranz, u: Synthesis philosophica 46(2008.), 333337.

${ }^{31}$ B. HÄRING, Kristov zakon, 467.

${ }^{32} \mathrm{McD}$ owell govori o djelovanju krjeposti u dvama pravcima: $\gg$ od vani prema unutra $\ll$ te $\gg$ od unutra prema vani «. J. MCDOWELL, Mind. Value and Reality, Cambridge, 1998., 50.

${ }^{33}$ Spomenimo još jednu oznaku krjeposti na koju upućuje MacIntyre. Polazeći od fragmentiranosti života današnjega čovjeka, on kaže da mu upravo krjepost pomaže kako bi ta različita područja, 


\subsection{OD PODNOŠENJA DO KRJEPOSTI TOLERANCIJE}

Zašto je potrebno govoriti o toleranciji kao krjeposti? Nerijetko se u svakodnevnom životu tolerancija doživljava samo kao prihvaćanje drukčijih mišljenja ili stavova i to radi izbjegavanja sukoba ili mogućih nesporazuma. Krajnji cilj tolerancije bio bi omogućiti (miran) suživot jednih pored drugih, ali bez istinskoga interesa za drugoga, za njegov način razmišljanja i njegov način traženja istine. Stoga je i suživot, ako se vodi tolerancijom kojoj je glavni cilj izbjegavanje sukoba pod svaku cijenu, veoma krhak i nesiguran. Takvu toleranciju, odnosno podnošenje drugoga, ali bez istinskoga interesa za njega kao osobu, neki nazivaju pasivnom tolerancijom. ${ }^{34}$ Društvo u kojem prevladava takvo shvaćanje tolerancije gotovo redovito je prožeto praktičnim indiferentizmom, a pitanje istine u takvom ambijentu gotovo je irelevantno. Problem koji se ovdje javlja i koji želimo istaknuti može se formulirati pitanjem: Može li se autentični (su)život utemeljiti na odnosima koji ne polaze od zanimanja za drugoga? Drugim riječima, može li se govor o toleranciji ograničiti samo na prihvaćanje načela koja će jamčiti suživot? Smatramo da istinska tolerancija treba imati u vidu osobu i da polazi od odnosa koji se među osobama uspostavlja, na čemu se i temelji zajednički život. To konkretno znači da treba usvajati modele i načine života koji se ne ograničavaju samo na indiferentno prihvaćanje drugoga, već se u njemu treba prepoznati osobu.

Krjepost tolerancije zahtjevna je jer podrazumijeva spremnost na izlazak iz sebe i suočavanje s izazovom življenja s onim koji misli ili postupa drukčije. ${ }^{35}$ Važno je istaknuti da takva otvorenost za drugoga i za njegov način razmišljanja ne znači nijekanje ili zanemarivanje vlastitih stavova. Tolerancija je, kako je rekao pokojni teolog Marasović, napor življenja uz $\gg$ tuđu $\ll$ istinu $i \gg t u đ u \ll$ praksu, a da se pritom ne napuste vlastita uvjerenja. ${ }^{36}$ Filozof McDowell upravo u sposobnosti suživota s onim tko misli drugačije vidi jednu od bitnih karakteristika krjeposti tolerancije. Da bi se to moglo ostvariti, potrebno je, prema njegovu mišljenju, stalno suočavanje $s$ vlastitim (prirodnim) impulsom jer svatko spontano odbacuje sve što se protivi vlastitim stavovima. Zato prihvaćanje drugoga u njegovoj različitosti nije

odnosno djelovanja objedinio i doživljavao kao jednu cjelinu: »Jedinstvo vrline u nečijem životu razumljivo je samo kao značajka jedinstvenog života, života koji se može pojmiti i vrednovati kao cjelina.«A. MACINTYRE, Za vrlinom. Studija o teoriji morala, Zagreb, 2002., 221.

${ }^{34}$ Usp. M. JOZIĆ, Tolerancija - povijest jedne ideje, 18.

${ }^{35}$ Usp. G. MANZONE, Società interculturali e tolleranza. Un contributo: la dottrina sociale della Chiesa, Assisi, 2004., 121.

${ }^{36}$ Usp. Š. MARASOVIĆ, Granice tolerancije, u: Vjesnik Đakovačke i Srijemske biskupije 7(1995.), 594-599., ovdje 595. 
tek plod nezainteresiranosti za postojeće, već znak jakosti osobe koja je kadra kontrolirati vlastito djelovanje. ${ }^{37}$

Je li tolerancija nešto što je prepušteno našemu izboru ili smo dužni tolerantno djelovati? Profesor Meilhammer smatra da tolerancija nije samo pitanje izbora, već smo dužni djelovati tolerantno. U prilog toj tezi on navodi nekoliko razloga. Polazi od prava osobe na vlastito uvjerenje bez obzira hoće li se drugi s takvim mišljenjem slagati, hoće li ga prihvatiti ili možda odbiti. Drugi razlog za toleranciju on vidi u činjenici da svatko ima svoj put kojim dolazi do istine te smatra da bi taj put drugi trebali poštivati. Kao treći razlog on ističe da u nekim situacijama argumenti koje neka osoba navodi mogu biti pogrješni, a da sama osoba možda u tom trenutku toga i nije svjesna. ${ }^{38}$ Postoje situacije u kojima se, gledano pod etičkim vidom, tolerancija ne samo pretpostavlja već i smatra etički obvezatnom. Forst kao primjer za tu tezu spominje toleranciju roditelja prema djeci, toleranciju između prijatelja ili pripadnika iste vjerske zajednice. ${ }^{39}$ Smatra da je temelj tolerancije, za koju se može pretpostavljati da je obvezna, sudjelovanje u ostvarenju zajedničkoga dobra koje se kroz toleranciju ostvaruje.

\subsection{KRJEPOST TOLERANCIJE - RAZINE DJELOVANJA}

Krjepost tolerancije može se promatrati na više različitih razina: kao odnos prema sebi samomu; kao odnos s drugima te kao odnos koji se uspostavlja unutar širega društvenoga konteksta. ${ }^{40}$

Toleranciju na prvoj razini promatramo kao odnos prema sebi samomu. Svatko je ponajprije pozvan tolerirati samoga sebe. Konkretno, to znači prihvaćati sebe i vlastitu stvarnost, posebno ono što sama osoba doživljava da je drukčije od onoga što očekuje. Ponekad će krjepost tolerancije biti poziv na dosljednost u ustrajnom prihvaćanju vlastitoga stava što može biti mnogo teže od prepuštanja općeprihvaćenom mišljenju. »Nije naime samo netko drugi drukčiji u odnosu prema nama, nego smo jednako tako i mi drukčiji u odnosu prema tome drugome, što će reći da nam valja uvažavati i tu svoju vlastitu različitost strpljivo podnoseći sve izazove i poteškoće koje to sa sobom nosi. Postupati eventualno drugačije značilo

\footnotetext{
${ }^{37} \mathrm{Za}$ McDowella je to prva od dviju bitnih karakteristika krjeposti tolerancije. Druga je sposobnost odabira i opredjeljenja unutar različitih mogućnosti kako bi se na ispravan način moglo suočavati s konfliktnim situacijama. Usp. J. MCDOWELL, Mind. Value and Reality, 664-665.

${ }^{38}$ Usp. E. MEILHAMMER, Tolerance and Truth in Intercultural Dialogue: Some Reflections, u: C. KANZIAN, E. RUNGGALDIER (ur.), Cultures. Conflict - Analysis - Dialogue. Proceedings of the 29th International Ludwig Wittgenstein-Symposium, Kirchberg, 2007., 249-260., ovdje 258.

${ }^{39}$ Usp. R. FORST, Toleranz im Konflikt, 658.

${ }^{40}$ Usp. Š. MARASOVIĆ, Granice tolerancije, 595-599.
} 
bi odreći se onoga istoga ljudskoga dostojanstva koje inače drugom priznajemo i koje u drugom poštujemo. $\ll^{41}$ Krjepost tolerancije u odnosu prema samomu sebi doživljava se kao suprotnost rezigniranom prepuštanju postojećoj situaciji i prihvaćanju izazova vlastitoga puta koji može biti drukčiji ili čak suprotan očekivanjima drugih.

Na drugoj razini krjepost tolerancije promatra se kroz odnose koji se uspostavljaju s drugim osobama. Tolerancija potiče na osjetljivost za drugoga i poziva na prihvaćanje drukčijega (mišljenja, stava). Da bi se to moglo ostvariti, potrebno je razumjeti njegov svijet, njegov način rasuđivanja i traženja istine. Ne treba gubiti iz vida da u središtu tolerancije nije toleriranje neke alternativne istine, mišljenja ili stava, već je u središtu prihvaćanje, toleriranje same osobe. Drugi vatikanski sabor u tom vidu ističe važnu razliku između prihvaćanja osobe kao takve i njezina mišljenja (čak i zablude): »Valja, međutim, razlikovati između zablude koju treba uvijek odbaciti i zabludjeloga, koji stalno zadržava osobno dostojanstvo osobe, pa i kad je opterećen krivim ili manje točnim religioznim shvaćanjima. $\ll{ }^{42}$

Treća razina krjeposti tolerancije odnosi se na relacije unutar različitih društvenih skupina, naroda i, općenito, djelovanja na globalnim razinama. ${ }^{43} \mathrm{O}$ toleranciji na tim razinama danas se veoma mnogo govori zbog različitosti kultura i civilizaci-

${ }^{41}$ Isto, 596.

${ }^{42}$ DRUGI VATIKANSKI KONCIL, Pastoralna konstitucija o Crkvi u suvremenom svijetu »Gaudium et spes $\ll(=G S)$, u: Dokumenti, br. 28.

${ }^{43} \mathrm{O}$ toleranciji unutar različitih kultura piše u svojoj knjizi: M. WALZER, On Toleration, New Haven - London, 1997. U kratkim crtama predstavit ćemo nekoliko režima, odnosno sustava tolerancije koje Walzer spominje. U starim društvima, tj. multinacionalnim carstvima (Stara Perzija, Egipat, Rim i Osmansko Carstvo) prepoznaju se modeli tolerancije koji se mogu razumjeti polazeći od nacionalno-vjerskih razlika. On smatra da se u takvom kontekstu toleriraju neke nacionalno-vjerske skupine, ali ne i pojedinci. Polazeći od moći vladara, skupine su bile prisiljene na međusobno podnošenje (Isto, 14-19.). Drugi se model odnosi na međunarodno društvo država. Taj model određen je s jedne strane načelom suvereniteta, a s druge pravnom doktrinom. Takvo djelovanje on naziva humanitarna intervencija (Isto, 19-22.). Treći model odnosi se na sudruštva ili konsocijacije, tj. na države u kojima živi više naroda, a različite skupine pozvane su jedna drugu tolerirati. Ovdje postoji strah da će se konsocijacija pretvoriti u naciju državu (Isto, 22-24.). Četvrti model počiva na državi naciji. U središtu su pojedinci. Riječ je o homogenom kulturnom prostoru. Oni koji se ne prilagode standardnoj kulturi toleriraju se na temelju statusa manjine (Isto, 24-30.). Na koncu on govori o imigracijskim društvima u kojima briga nacije države za pojedinca postaje sve naglašenija. $S$ obzirom na to da imigracijskom društvu nedostaje (etnička) homogenost, u takvom se društvu potiče tolerancija. Ni jednoj skupini ne dopušta se da se nameće drugima ili preuzima kontrolu nad javnim prostorom ili ovladava javnim resursima. Država je neutralna u pogledu kultura pojedinih skupina, ali ih sve podupire (Isto, 30-35.). 
ja, sve brojnijih migracija, kao i dodira različitih religija. ${ }^{44} \mathrm{Ne}$ zalazeći dublje u tu aktualnu i izazovnu temu, samo ćemo ukazati na dva pitanja: Trebamo li uvijek, pod bilo kojim uvjetima, biti tolerantni te gdje su granice tolerancije? Već je prije spomenuto da tolerancija nije bezgranična. Stoga autentična tolerancija u nekim situacijama pretpostavlja netolerantno djelovanje. U tom vidu može se govoriti o paradoksu tolerancije, tj. o toleranciji koja nije tolerantna. Filozof Forst navodi tri aktualna izazova netolerantnoga djelovanja: toleriranje rasizma; toleriranja nečega što je moralno loše ili neprihvatljivo te na koncu i samo suočavanje s pitanjem određenja granica kojima se ograničava tolerancija. ${ }^{45}$

Govoreći o granicama tolerancije, temeljno načelo jest opće dobro. Naime tolerancija nije cilj ili svrha samoj sebi, već se ona treba povezati i treba biti usmjerena prema ostvarenju općega dobra. ${ }^{46}$ Zato sve ono što se protivi općemu dobru ne bi se smjelo tolerirati. U tom vidu država, polazeći od njezine uloge, odnosno odgovornosti za ostvarenje općega dobra, ima pravo određivati granice tolerancije ondje gdje bi eventualno prekoračenje ugrožavalo interese općega dobra. Pitanja koja se ovdje otvaraju odnose se na definiranje općega dobra u kontekstu današnjega pluralnoga i složenoga društva, što nije uvijek jednostavno učiniti.

I unutar demokratskoga društva, unatoč činjenici da se ono redovito predstavlja tolerantnim i načelno jamči pravo na slobodu mišljenja i djelovanja, opravdano je postaviti pitanje o tome kako se toleriraju drukčija mišljenja i drukčiji svjetonazori. Dobivaju li oni koji su drukčiji u javnosti primjereno mjesto ili im se taj prostor ograničava upravo zbog njihove različitosti (npr. u odnosu na javno mnijenje, politiku ili neke druge interese). Zato je i aktualno promišljanje teologa Šarčevića koji upozorava na to da je danas sve manje prisutan govor o Bogu i da se ignorira govor

\footnotetext{
${ }^{44}$ Poput ostalih krjeposti i krjepost tolerancije može se promatrati polazeći upravo od vrijednosne strukture nekoga društva. MacIntyre u tom vidu radi razliku između društva u kojem se pretežno dijele vrijednosni sustavi (vrijednosti je većina prihvatila) ili heterogenoga društva u kojem su vrijednosni sustavi i tradicije različite. Dok u prvom slučaju govori o tzv. primarnim krjepostima (poput lojalnosti - radi ostvarenja dobroga življenja), u drugom slučaju riječ je o tzv. sekundarnim krjepostima, a među njima na prvo mjesto stavlja toleranciju, odnosno sposobnost kompromisa. Vidi više u knjizi: A. MACINTYRE, Secularisation and Moral Change, London, 1967. Bares je kritičan prema takvom shvaćanju krjeposti tolerancije. On smatra da se potreba za tolerancijom doista prepoznaje $u$ heterogenim društvima, ali je ona potrebna u svakom društvu jer je intrinzična društvenom životu. Usp. B. BARNES, Tolerance as a Primary Virtue, u: Res Publica 7(2001.), 231-245., ovdje 239.

${ }^{45}$ Usp. R. FORST, Tolerance as a Virtue of Justice, u: Philosophical Exploration: An International Journal for the Philosophy of Mind and Action 3(2001.), 193-205., ovdje 193-195.

${ }^{46}$ Usp. K. RAHNER, Societa umana e Chiesa di domani, u: Nuovi saggi, X, Milano, 1986., 30-50., ovdje 37.
} 
o transcendentnom i božanskom..$^{47}$ Tolerancija u tom vidu kao da se pokazuje netolerantnom. Ona se $\mathrm{u}$ isto vrijeme želi predstaviti neutralnom, a zapravo postaje nesloboda, strah i osiromašenje. Pitanje o krjeposti tolerancije i u javnom prostoru i u osobnim odnosima vjernika treba suočavati s pitanjem: Tko je za mene drugi?

\subsection{HOD U KRJEPOSTI TOLERANCIJE}

Svaka krjepost, tako i krjepost tolerancije, pretpostavlja postupnost i rast. Talijanski teolog Manzone spominje tri koraka u rastu u krjeposti tolerancije. ${ }^{48}$ Prvi, početni korak jest suočavanje s izazovom prihvaćanja socijalnih i kulturnih razlika, bez čega nije moguće govoriti o prihvaćanju drugoga u njegovoj različitosti.

Drugi korak na putu izgradnje tolerancije krjeposti usmjerava prema izgradnji povjerenja i međusobnoga poštivanja. To je korak koji vodi dalje od samoga prihvaćanja. Drugu se osobu prihvaća, u njoj se prepoznaju vrijednosti i doživljava ju se kao nositelja vrednota. Zapreke na toj razini mogu biti predrasude ili neprijateljstva. Postojeće razlike ponekad mogu izgledati nemoguće ili teško savladive, te je stoga u izgradnji povjerenja važna postupnost. Umjesto velikih i brzih promjena realniji i uspješniji koraci ostvaruju se osluškivanjem drugoga, odnosno empatičnošću.

Treći korak u rastu krjeposti tolerancije usmjerava prema uspostavi prijateljstva. Iako se ne dijele ista vjerovanja ili isti sustav vrijednosti, ono što može povezivati i na čemu se može graditi prijateljstvo je prihvaćanje drugoga kao osobe. Suprotnost je takvom stavu netolerancija koja selektira i reducira prema određenim kriterijima (npr. etničkoj ili ideološkoj pripadnosti). Taj korak označava prijelaz od (su)života $s$ drugima prema životu za druge. Umjesto netolerancije koja eliminira, tolerancija na taj način oživljava sugovornika kao osobu u njezinoj punini. Posebni izazovi krjeposti tolerancije na tom stupnju jesu prihvaćanje drugoga, ali isto tako i spremnost na vlastitu promjenu.

Različitost onih koji ostvaruju susret, bilo da je riječ o dijalogu ili toleriranju, uvijek pretpostavlja identitet kao svijest o sebi, svojoj posebnosti, kao i svijest o onome što od drugoga razlikuje. Zapravo, poznavanje samoga sebe nužan je korak da bismo mogli uočiti različitosti drugoga, odnosno njegov identitet.

\subsection{KrJePOST TOLERANCIJE - Ugroza AUTONOMIJE?}

Iako mnogi, počevši već od Cicerona, ističu zahtjevnost tolerancije (npr. samokontrola ili podnošenje teških situacija), $\mathrm{s}$ druge strane mogu se čuti prigovori da

\footnotetext{
${ }^{47}$ Usp. I. ŠARČEVIĆ, Govor o Bogu u dobu tolerancije. Bogobojaznost - strahopoštovanje - milosrđe, u: Vjesnik Đakovačko-osječke nadbiskupije i Srijemske biskupije 17(2005.), 897-901.

${ }^{48}$ Usp. G. MANZONE, Società interculturali e tolleranza, 123-130.
} 
je tolerantno djelovanje znak slabosti jer tolerantna osoba nije dosljedna vlastitim načelima te prihvaća tuđa mišljenja i tuđe stavove. Predstavlja li tolerancija ugrozu za autonomiju osobe?

Njemački filozof Friedrich Nietzsche, govoreći o toleranciji, kaže da se ona veoma dobro uklapa u kontekst današnjega doba. Tolerantno prihvaćanje drugoga, njegovih stavova i mišljenja za njega je u prvom redu znak nesposobnosti današnjega čovjeka da djeluje na temelju vlastitoga uvjerenja i vlastite autonomije. Zato, kaže Nietzsche, tolerancija je svojevrsno poricanje samoga sebe, nijekanje vlastite originalnosti i jedan od pokazatelja krize identiteta. ${ }^{49}$ Ona je plod slabosti, nesigurnosti i nepovjerenja u samoga sebe. Tolerancija je, na koncu ističe Nietzsche, izraz nemogućnosti zauzimanja vlastitoga stava i nespremnosti da se odlučno slijedi takav stav. Ona je izraz čovjekove nesposobnosti da odlučno izreče da ili ne!

U odgovoru na taj prigovor treba računati na ozbiljnost Nietzscheove primjedbe, posebno kada govori o krhkosti današnjega čovjeka. Međutim upravo takva situacija ugroženoga čovjeka još više naglašava važnost krjeposti tolerancije. Suprotno od onoga što govori Nietzsche, krjepost tolerancije pretpostavlja jaku osobnost koja je svjesna vlastitoga uvjerenja i koja unatoč različitosti, prihvaća drugoga u njegovoj različitosti ostajući dosljedna vlastitom uvjerenju. Zato krjepost tolerancije nije rezultat nemogućnosti zauzimanja vlastitoga stava ili nedosljednosti u vlastitom opredjeljenju. Zapravo je netolerancija, a ne tolerancija, znak slabosti osobe jer ona označava nesposobnost za život $s$ različitim od nas. Tolerancija svjedoči o jakosti i unutarnjoj slobodi osobe koja prihvaća i može suživjeti uz onoga koji je drukčiji.

Druga primjedba polazi od tvrdnje da nije moguće govoriti o toleranciji kao krjeposti jer se ona ograničava samo na čovjekovo razumsko djelovanje. ${ }^{50}$ Konflikti s kojima se treba suočiti i koji zahtijevaju tolerantno postupanje rješavaju se isključivo razumskim putem. Međutim krjeposno djelovanje ne ograničava se samo na iznalaženje razumskoga rješenja. Tolerancija pretpostavlja angažman cjelokupne osobe. Istina je da je potrebno razumjeti situaciju kako bi se moglo razmišljati i o različitim aspektima djelovanja. Pritom treba istaknuti da tolerancija zahtijeva suočavanje sa svakom situacijom posebno: »U svakoj prilici, osoba zna što treba učiniti ali ne primjenjujući univerzalna načela već djelujući u skladu s vlastitim karakteristikama. ${ }^{51}$ Opredjeljenje za tolerantno djelovanje podrazumijeva spremnost da se izloži riziku (ne)uspjeha, da ne bude shvaćena ili čak da bude odbijena. I to govori u prilog činjenici da tolerantno djelovanje nije isključivo refleksivne prirode. Upravo je ta

\footnotetext{
${ }^{49}$ Citirano prema R. FORST, Tolerance as a Virtue of Justice, 203.

${ }^{50}$ Usp. isto, 668-669.

${ }^{51}$ J. MCDOWELL, Mind. Value and Reality, 73.
} 
etička dimenzija tolerancije prepoznatljiva u procesu odlučivanja jer uključuje promišljanja i unutarnje konflikte te spomenutu spremnost na preuzimanje rizika.

Treća primjedba govori o podijeljenosti osobe koja djeluje tolerantno. Ta bi podijeljenost bila u tome da tolerantna osoba prihvaća stavove drugih, a u isto vrijeme bi trebala ostati dosljedna vlastitim stavovima. ${ }^{52} \mathrm{Ta}$ je podijeljenost posebno očita kada treba prihvaćati život unutar različitih vrijednosnih, ideoloških, etičkih ambijenata. Međutim činjenica da netko suživi s onima koji misle drukčije ne mora značiti da će nužno kao osoba biti u sebi podijeljen. U takvim slučajevima trebalo bi govoriti o životu koji se oblikuje unutar pluralnog ambijenta. Istina je da je to ponekad veoma zahtjevno jer podrazumijeva oblikovanje vlastitoga identiteta u neprestanoj interakciji s različitim kontekstima i stalna propitkivanja vlastitih stavova. Pritom nije cilj reduciranje ili nijekanje složenosti situacija (ako je to uopće ostvarivo), već zauzimanje stavova pred raznim ponudama. Važno je spomenuti da je uvijek riječ o jednom identitetu koji se oblikuje u interakciji s različitim ambijentima.

\subsection{KRJEPOST TOLERANCIJE I VJERSKO NADAHNUĆE}

U Božjoj ljubavi, u Njegovu prihvaćanju čovjeka i svijeta, ${ }^{53}$ vjernik nalazi nadahnuće za vlastito djelovanje. Bog nije onaj koji pasivno podnosi čovjeka, već mu otkriva svoju ljubav koju je posvjedočio utjelovljenjem, životom, smrću i uskrsnućem. »Uistinu, Bog je tako ljubio svijet te je dao svoga Sina Jedinorođenca da nijedan koji u njega vjeruje ne propadne, nego da ima život vječni.« (Iv 3, 16) Božja ponuda spasenja obuhvaća sve ljude jer On hoće $\gg$ da se svi ljudi spase i dođu do spoznanja istine « (1 Tim 2, 4). Upravo iz perspektive spasenjske zauzetosti za čovjeka može se razumjeti Božje djelovanje kroz cijelu povijest spasenja, od Adama sve do danas. Bog djeluje da bi čovjeka pridigao, oslobodio od grijeha i obdario ga milošću. Nije riječ samo o pojedinim zahvatima ili epizodama u ljudskoj povijesti, već je to stalan kriterij Božjega djelovanja.

U Božjoj objavi čovjek otkriva vlastitu veličinu, odnosno vlastito dostojanstvo. Vjerovanje da je svaka osoba Božja slika i Božje stvorenje osnažit će vjernika da bi mogao prihvaćati drugoga bez obzira na to je li on netko u Crkvi ili izvan nje. Priznavanje transcendentne dimenzije svakoga čovjeka utvrdit će u opredjeljenju za

${ }^{52}$ Usp. R. FORST, Toleranz im Konflikt, 669-670.

${ }^{53}$ Kada se govori o Božjem prihvaćanju svijeta, tada se pod pojmom svijet misli na »cjelokupnu ljudsku obitelj sa sveukupnom stvarnošću u kojoj živi; svijet kao pozornicu povijesti čovječanstva, obilježen njegovim pothvatima, njegovim porazima i pobjedama. Kršćani vjeruju da je taj svijet, ljubavlju Stvoriteljevom sazdan i uzdržavan, doduše dospio u ropstvo grijeha, no da ga je raspeti i uskrsli Krist, slomivši moć Zloga, oslobodio da se prema Božjem planu preobrazi i ako dođe do svoje potpunosti $\ll(G S$, br. 2$)$. 
tolerantno djelovanje i osnažiti u prihvaćanju drugoga. U Bibliji vjernik nalazi nadahnuće za tolerantno djelovanje prema svakomu čovjeku, kao i za toleranciju unutar same Crkve. Teolog Zovkić ukazuje na Pavlov tekst u kojem, prema njegovim riječima, leži posljednji dogmatski razlog takve tolerancije: $\gg$ A Bog postojanosti i utjehe, dao vam da međusobno budete složni poput Isusa Krista, te jednodušno, iz jednoga grla, slavite Boga i Oca Gospodina našega Isusa Krista. Prigrljujte jedni druge kao što je Krist vas na slavu Božju. « (Rim 15, 5-6 $)^{54}$

Naša zajednička humanost i sveopće bratstvo koje vjernik prepoznaje u Božjem prihvaćanju čovjeka i ponuđenom očinstvu platforma je na kojoj se može temeljiti krjepost tolerancije. $\gg$ Polazište za vjerničku toleranciju nije strah, nego ponizna zagledanost pred Tajnom svijeta, pred onim posve Drugim. To je posljednje utočište i najhrabrijih misli i kriterij svakoga djelovanja. Na ovom se stupnju utemeljuje i tolerancija, i to ne kao poštivanje razlika, nego kao zajedničko stajanje pred istim autoritetom iz kojega proizlaze sve razlike i koji te razlike ne samo podržava nego potvrđuje i ljubi. $\ll^{55}$

\section{Zaključak}

Tolerancija raste dijalogom, a istovremeno istinski dijalog plod je tolerancije. Riječ je o dijalogu koji se ne shvaća samo kao tehnika ili umijeće priopćavanja, već kao put ostvarenja susreta. Takav dijalog pretpostavlja otvorenost prema sugovorniku bez obzira na to je li on sličnih ili suprotnih pogleda. Autentični dijalog, polazeći od naučavanja pape Benedikta XVI., treba shvatiti kao dia-logos, tj. kao put k istinskom susretu u zajedničkom traženju istine. ${ }^{56}$ Prepreke uspostavi takvoga dijaloga mogu biti predrasude, ali i zarobljenost vlastitom istinom koja se želi drugomu nametnuti. Takav stav onesposobljava za slušanje argumenata drugih, ali i za vlastito korigiranje. Zato je krjepost tolerancije usko povezana sa sviješću o vlastitim granicama te skromnošću koja se rađa iz takvoga stava. Teolog Marasović u skromnosti vidi nužni uvjet tolerancije jer ona »kao vrlina, može uspijevati samo u određenom mentalnom podneblju, u onom naime gdje vlada intelektualna skromnost (što i jest osobina prave inteligencije), a ne intelektualna samodopadnost i isključivost $\ll .{ }^{57}$

Dijalog je danas jamstvo opstanka pluralizma, a bez njega se suočavamo s opasnošću zatvaranja u isključujuće skupine. Stoga je, pogotovo za vjernike, važan poziv na dijalog, bilo da je riječ o onima u Crkvi ili izvan nje, o čemu govori Drugi vatikanski

\footnotetext{
${ }^{54}$ M. ZOVKIĆ, Tolerancija u Crkvi, u: Crkva u svijetu 18(1983.), 344-349., ovdje 347.

${ }^{55}$ I. ŠARČEVIĆ, Govor o Bogu u dobu tolerancije, 900.

${ }^{56}$ BENEDIKT XVI., Caritas in veritate. Ljubav u istini, Zagreb, 2010., br. 4.

${ }^{57}$ S. MARASOVIĆ, Granice tolerancije, 597.
} 
sabor: $\gg$ Poštovanje i ljubav moraju se protegnuti i na one koji u društvenim, političkim ili vjerskim stvarima misle ili postupaju drukčije od nas; jer što s većom čovječnošću i ljubavlju budemo dublje razumjeli njihove načine, to ćemo lakše moći s njima zapodjenuti razgovor. $\ll{ }^{58}$ Polazeći od koncilskoga shvaćanja dijaloga, teolog Šagi Bunić ističe da se dijalog treba graditi polazeći od triju temeljnih spoznaja: u dijalog ne ulaze ni ideologije ni znanosti, već konkretni ljudi; nije odlučujuće za uspjeh dijaloga da sugovornici imaju isto mišljenje o temama o kojima razgovaraju; kada se istina spozna, sugovornici moraju biti spremni istinu prihvatiti. ${ }^{59}$

Prije nego podnošenje tuđega stava, tolerancija je priznavanje i prihvaćanje drugoga kao osobe. Nije tolerancija krajnji cilj koji treba ostvariti, već je ona ponuda i poziv za izgradnju odnosa. Ona je put ostvarenja zajedništva i značajan korak u oblikovanju novoga modela civilizacije otvorene različitosti. Nije potrebno isticati u kojoj bi mjeri edukacija za iskreni dijalog trebala postati zadaća pedagoških institucija, Crkve, kao i cijeloga društva. Društva koja žele odgajati za istinsku demokraciju nastojat će u promociji tolerancije na svim razinama.

Pogled na društvenu i osobnu stvarnost pokazuje da je potpuno slaganje u svim pitanjima s kojima nas život suočava, zapravo, iluzija. Stoga je stalno prihvaćanje različitosti put izgradnje suživota. Jedinstvo koje se želi ostvariti gradi se na poštivanju slobode i različitosti, a ljubav je ona koja sve prožima: In necessariis unitas, in dubiis libertas in omnibus charitas. (Jedinstvo u onome što je nužno, slobodno razmišljanje u onome što je otvoreno, a u svemu ljubav.)

${ }^{58}$ GS, br. 28.

${ }^{59}$ Usp. T. J. ŠAGI-BUNIĆ, Ali drugog puta nema. Uvod u misao Drugog vatikanskog koncila, Zagreb, 1969., 377-380. 


\title{
TOLERANCE - FROM ENDURING TO VIRTUE
}

\author{
Jerko VALKOVIĆ*
}

Summary: The presence of different worldviews, values, cultures, and religions, that marks today's plural society, gives rise to discourse on tolerance. In the paper, the author does not speak of tolerance as a »necessary principle $\ll$ of coexistence within one society, nor does he see tolerance as merely »enduring « different positions or opinions. The author reflects on grounding tolerance starting with the person. He sees tolerance as the moral attitude of a person who respects the freedom of others and their path in searching for truth. Accepting the other as a person is the foundation of authentic tolerance. The virtue of tolerance is not just one of the >characteristics « of personality, but it is the habitus. It permeates the very core of man and is recognized in action in different areas of man's life. The virtue of tolerance presumes constant growth and maturation, while a person of faith, in observing God's love, finds in faith an inspiration for tolerant action.

Keywords: tolerance, the virtue of tolerance, person, enduring, truth, dialogue.

\footnotetext{
* Assoc. Prof. Jerko Valković, Ph. D., Catholic University of Zagreb, Ilica 242, 10000 Zagreb, Croatia, jerko.valkovic@unicath.hr; Theology Department in Rijeka - Dislocated Studies of the Catholic Faculty of Theology, University of Zagreb, 51000 Rijeka, Croatia.
} 